\title{
BASIlio SÁNChez y EL FERVOR POÉTICO: HE HEREDADO UN NOGAL SOBRE LA TUMBA DE LOS REYES
}

\author{
CARMEN MARÍA LÓPEZ LÓPEZ \\ Universidad Católica San Antonio de Murcia
}

Si por algo viene caracterizándose la voz poética de Basilio Sánchez (Cáceres, 1958), es por la lentitud de su cadencia, por el verso detenido, por el fervor y el sosiego. La lentitud permite que el poeta sea y se haga uno con la tierra, se congracie con la semilla, comulgue con lo virginal. Tales cualidades son la insignia de su último libro, He heredado un nogal sobre la tumba de los reyes (2019) ${ }^{1}$, galardonado con el trigésimo primero Premio Internacional de Poesía Fundación Loewe. En términos estructurales, el poemario presenta una estructura tripartita a la que sigue una coda, final o cierre que intensifica y recapitula aquellos elementos esparcidos -tras la diseminatio retórica- a lo largo del libro. El sentido unitario de cada sección (I: «Hay un olor de agua y de resinas»; II: «Mi mesa de madera es del tamaño de un nido»; III: «El mar ha edificado una iglesia a la salida del sol») estriba en el encadenamiento de las partes: el verso con que concluye una se instaura como leitmotiv poético de la siguiente, y así se engarzan en un perpetuum mobile hasta crear en el lector el efecto de una especie de continuidad del poeta con las cosas y con las palabras que dan nombre a los seres del mundo.

La mirada perpleja de Basilio Sánchez abarca una amplísima diversidad de motivos poéticos. Sin embargo, son dos los ejes que enhebran subrepticiamente la materia temática de los poemas: la reflexión metaliteraria sobre qué sea escribir poesía y de qué modo cante la figura del poeta; y la naturaleza como escenario y reino de inagotable potencial expresivo. De uno y otro lado el poeta es ese ser atento que está ahí, como el que escucha las voces y los ecos para ser luego canto. ¿Qué es el poeta? Aquel que desvela el milagro del mundo. Quien, por una sensibilidad especial, se dispone a cantar la alegría minúscula, viva, cotidiana.

\footnotetext{
${ }^{1}$ Basilio Sánchez, He heredado un nogal sobre la tumba de los reyes, Madrid, Visor, 2019.
} 


\section{Las palabras son mi forma de ser}

Basilio Sánchez, médico de profesión, cree en el poder curativo de las palabras. El verbo poético deviene bálsamo cicatricial de las heridas. La escritura salva de algo. No sabemos de qué, pero nos salva. Y las palabras son la huella que sobre el papel imprime ese don medicinal del lenguaje. «Las palabras son mi forma de ser» (2019: 81), reza el verso que cierra este poemario telúrico, genesíaco. La palabra se remansa, detenida, ante el misterio insondable de la creación. El resultado estético es una visión del mundo contemplativa, austera, casi mística (2019: 22):

Amo lo que se hace lentamente,

Lo que exige atención,

Lo que demanda esfuerzo.

Amo la austeridad de los que escriben

como el que excava un pozo

o repara el esmalte de una taza.

Mi habla es un murmullo, una simple presencia que en la noche, en las proximidades del vacío, se impone por sí sola contra el miedo, contra la soledad que nos revela lo pequeños que somos.

El poeta no ha elegido el futuro.

El poeta ha elegido descalzarse en el umbral del desierto.

Cantor de lo sencillo, el poeta es ese ser que camina descalzo en el desierto. Hay en él un canto hecho de ecos y murmullos. El poeta alcanza la plenitud lírica de lo que no se explica: «La poesía no explica ni argumenta/ la poesía sólo llama a las cosas» (2019: 44). La actividad poética se distancia del discurso racional para deslizarse por el territorio de lo que María Zambrano nombró como «razón poética», oxímoron en que se ensamblan dos conceptos en apariencia discordantes pero que, bajo su mirada lírica, se conjugan en íntima claridad. 


\section{El poeta es el hombre arrodillado}

En la visión creadora de Basilio Sánchez, el poeta no es un sacerdote, no habla el lenguaje de los dioses, sino el de los hombres. Dista de ser un chamán o una figura mesiánica dotada de poderes sobrenaturales para aproximarse a quien escucha el rumor de lo pequeño, la sinfonía callada de las cosas, de los árboles, del mundo: «El poeta es el hombre arrodillado» (2019: 14). Truncada la comunicación directa entre el poeta y la divinidad, el primero condesciende a su oficio secreto: el canto de las cosas cotidianas.

La certeza de que el Paraíso es un lugar inaccesible sitúa como centro una incógnita, un desgarramiento del yo, una nostalgia del absoluto: "Ya no cabe en nosotros el asombro, / la costumbre de la perplejidad. / No nos quedan lugares en los que sea posible lo absoluto» (2019: 35). Queda entonces una nostalgia arcana, un sentimiento de lo primordial, una comunión del hombre con las cosas. De la perplejidad del poeta persiste ahora una contemplación serena, un eco rumoroso, una voluntad de recogimiento. Es como si la poesía solo pudiera brotar en los lugares más puros, en aquellos recodos intocados por la mano del hombre, en el verde primordial, en las alas de los pájaros (2019: 42):

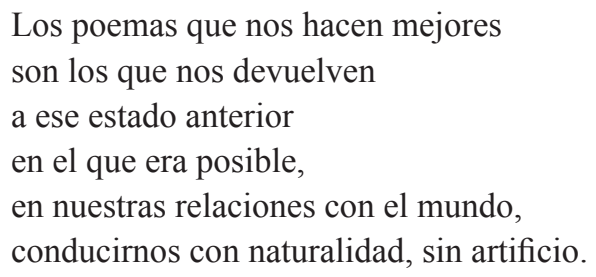

La pérdida del reino descarta toda posible pretensión de unidad íntima con la divinidad y, sin embargo, es el afecto el don que barniza las cosas de un halo sagrado: "Acercarnos con afecto a las cosas / permite intimar con lo sagrado / que permanece en ellas» (2019: 17). Basilio Sánchez cree, como Hölderlin, en la aristocracia del espíritu. La pureza del corazón se desprende de toda grandilocuencia. Queda entonces un lirismo en harapos, un sentido místico del mundo de los que han sido arrojados del Paraíso: «Cuando escribo /paseo con un ángel / arrojado innecesariamente del paraíso» (2019: 16). 


\title{
Poesía del ser
}

He heredado un nogal sobre la tumba de los reyes es poesía del ser, poesía de la esencia, poesía reducida a la materia esencial de donde brotan las cosas. En comunión con la naturaleza, el poeta nombra la luz, la tierra a tientas, las palabras. Una imagen reiterada como la de las grutas, se eleva en condición de símbolo de la oquedad esencial. El lirismo nace de las cosas, la materia viva que en su pequeñez dota de sentido al mundo. Una piedra de sílex, la cera de una abeja, un riachuelo, un árbol a la sombra de un camino, una gota de agua del diluvio, bastan para que la palabra sea, además de palabra, poesía (2019: 63):

\author{
El lenguaje \\ te obliga a decir bien lo que has oído \\ de la brizna de hierba, \\ lo que intuyes de la gota de ámbar, \\ lo que no has comprendido de la vida.
}

El oído atento del poeta capta los matices de las cosas. Así se hace el lenguaje. De la incomprensión de la vida nace el impulso de nombrar, inequívocamente, el gozo cotidiano, el don de la gratitud, la contemplación serena. El poeta entona entonces la plegaria del hombre conmovido: «Me conmueve la humildad de los pájaros / que trabajan día y noche para trenzar un nido / en un árbol sin nombre» (2019: 42). La poesía es también ese lugar de lo que no tiene nombre. Aquello que está más allá del lenguaje. Aquello que el poeta traduce de los dulces sonidos de la naturaleza y del mundo.

Los ecos primordiales confieren al verso una naturalidad que destierran toda posible impostación o artificio. De la desnudez se origina una subyugante belleza. Solo cuando la poesía se desprende de la hojarasca, cuando pierde el alambique, hay pureza en el canto. Basilio Sánchez capta ese momento milagroso del desprendimiento, de la resta como opción artística para sumar así intensidad lírica sin desvirtuar la emoción del conjunto. Hay en el libro un hilo anuda los versos de los poemas. Ninguno tiene título. Nombrar es limitar, como la tarea yerma de etiquetar el continuum de la naturaleza. ¿Acaso un título podría nombrar con vocación de verdad la plenitud del canto?

La música de la poesía está en la naturaleza, en la resina esencial del árbol, en la piedra de sílex de algún árbol sin nombre. Y así, entre el fervor del origen y la esperanza de perpetuidad, se ilumina la gruta del lenguaje. En nada se distinguen los primeros pobladores que trazaban símbolos sagrados sobre la piedra de una cueva y 
quien ahora escribe sobre un papel en blanco. Idéntico caldo primigenio prevalece en ambos actos creativos, porque escribir es -ante todo- volver al origen: «Escribir un poema / supone, de algún modo, regresar / otra vez al principio» (2019: 63). Esta regresión a la semilla de las cosas alberga un territorio donde reina la noche. Escribir es vivir a oscuras. Pero una oscuridad plena, redentora. Las tinieblas de la poesía conducen a la orilla del misterio: «Escribir un poema es sumergirse / en las profundidades de otra noche, / vincularse al misterio / de un cielo sin estrellas [...]» (2019: 29). Tal anhelo de trascendencia poética permite intimar con lo sagrado: «Hay que estar muy adentro en la circunferencia de la noche/ para encontrar las cosas que nos salvan la vida. / Ninguno de nosotros/ está aún preparado para lo incomprensible» (2019: 46).

Eremita de lo bello, Basilio Sánchez convoca una escritura en estado de gracia que nos acerca a los dones del silencio y, de ahí, a la grandeza del corazón. Poesía que, tras la devastación, hará crecer perpetuamente un nogal sobre las losas de las tumbas. 